\title{
Językoznawca jako badacz mediów (zarys problematyki)
}

\author{
Linguist as a media researcher (an outline of the issue)
}

\author{
Maria Wojtak \\ Wydział Humanistyczny, Uniwersytet Marii Curie-Skłodowskiej, \\ pl. Marii Curie-Skłodowskiej 4 A, 20-031 Lublin, Polska; \\ e-mail: maria.wojtak@poczta.umcs.lublin.pl
}

\begin{abstract}
The author presents the proceedings used by the linguists involved in the media research highlights dominant approaches, distinguishes two hypothetical ones: hegemonic and sovereign, and discusses challenges related to both of them. Hegemonic approach in the media research means the a distinctly defined subject of the study, that is the language of the media, precisely defined subject of analysis, namely the language of the media, and a supremacy of linguistic methods used in the analysis. The linguist as a sovereign prefers an open attitude towards methods applied in the study. Such an approach considers achievements of the media scholarshop as well as other related scientific disciplines. This attitude in the media research means that the linguist analyzes an image of the world in the media, a stylistic differentiation of the media communication, media genres, and the discourse. Furthermore, the linguist as a sovereign claims creating a new linguistic discipline and widens the research field with contrastive issues.
\end{abstract}

Keywords: media studies; linguistics; the language of media; the language of the press; media discourse; journalistic genres.

Medialne pole badawcze jest obecnie w Polsce zasiedlone przez wiele dyscyplin szczegółowych i stanowi podstawową dziedzinę poznawczą dla krzepnącego i dynamicznie się rozwijającego medioznawstwa. Jest to dziedzina naukowej eksploracji wyjątkowo zmienna ze względu na stan samej dyscypliny oraz charakter przedmiotu badań.

W niniejszym szkicu będę się starała nakreślić obraz możliwych form obecności językoznawcy na wspomnianym polu ${ }^{1}$.

Dlaczego mówię o możliwościach, miast dokumentować formy tej obecności przeszłe, obecne, a zwłaszcza postulowane (czy wręcz pożądane)? Skupienie uwagi na tym, co może robić lingwista, gdy włącza się w badania medioznawcze,

${ }^{1}$ Analogiczną problematykę prezentują inne publikacje autorki (Wojtak 2014; 2015:15-30). 
pozwala uniknąć stanowczych deklaracji na temat wątków, a więc i metod badawczych, które uznać można za przebrzmiałe z racji powiązań z niemodnymi dziś paradygmatami poznawczymi. Tymczasem wiadomo, że niektóre zagadnienia funkcjonują jako trwałe obszary badawcze, ponieważ nie znikają związane z nimi właściwości mediów. Można te kwestie rozwiązywać po staremu lub szukać nowych kategorii poznawczych, nowych zasad analizy, a zwłaszcza nowych reguł interpretacyjnych.

Współczesna nauka wpisuje się w ogólnokulturowe tendencje do pluralizmu ocen, postaw, działań. Labilność może być traktowana jako słowo klucz do wstępnego rozpoznania sytuacji badacza włączającego się w medialne pole poznawcze. Labilny, polimorficzny i wręcz niestabilny jest przedmiot badań. Badacza wkraczającego na takie pole powinna charakteryzować postawa otwartości, elastyczności i pokory, ale też odwaga $\mathrm{w}$ dążeniu do rozpoznania stopnia złożoności przedmiotu badań, a więc podjęcia prób dostosowania instrumentarium badawczego do nowej sytuacji poznawczej. W wielu opracowaniach zwraca się uwagę na współwystępowanie dwu postaw badawczych, czyli czasem desperackich zabiegów uchwycenia (zamknięcia) nowych zjawisk komunikacyjnych w starych kategoriach analitycznych lub równie desperackich prób poszukiwania nowych narzędzi analitycznych.

Postawa otwartości zaczyna dominować nie tylko wśród językoznawców wkraczających w medialną dziedzinę poznawczą. Tu jednak musi się ujawniać ze szczególną siłą. Jednym z najważniejszych jej składników jest poszukiwanie przemyślanego i rozsądnego eklektyzmu metodologicznego (Kita 2012: 14). Takie postawy cechują obecnie językoznawców wpisujących się w Polsce w badania nad mediami.

Sytuacja językoznawcy zainteresowanego badaniem mediów (początkowo jedynie prasy) zmieniała się i nadal podlega modyfikacjom. Jego pozycja zależała i zależy, co oczywiste, od stanu własnej dyscypliny oraz stanu badań nad mediami. Nie bez znaczenia jest tu zderzenie postaw samych językoznawców oraz tych badaczy mediów, którzy wywodzą swe dociekania z innych obszarów badawczych. Chcąc nakreślić obraz możliwych poczynań lingwistów badających media, odwoływać się będę do hipotetycznie skonstruowanego zbioru ról, jakie im przypadają z własnej woli bądź z medioznawczego nadania. Sama typologia ról oraz ich metaforyczna nominacja jest propozycją autorską, a więc wpisuje się w podmiotowy dyskurs współczesnej humanistyki (Wojtak 2014a: 164-165; 2015: 17-20).

Spośród owych ról na uwagę szczególną zasługuje rola lingwisty hegemona, jaką językoznawcy zaczynali odgrywać w medialnym teatrum badawczym. Rola ta obecnie jest jeszcze zauważalna, lecz sposób grania uległ radykalnym przeobrażeniom. Lingwista hegemon miał ściśle (czasem - z dzisiejszego punktu widzenia - zbyt ściśle i wąsko) zakreślony przedmiot badań, precyzyjnie wybrane i dobrane metody, jasno określone zakresy i cele analiz. Przedmiotem badań 
czynił mianowicie język mediów (początkowo jedynie prasy). Zakresy dociekań były różne. Dość długo dominowała problematyka poprawnościowa (Pisarek 2007: 201-214), opracowywana w zróżnicowanym zakresie i w różnorodny sposób. Przypisywano prasie rolę wzorca zachowań językowych, a opracowania naukowe o różnym stopniu szczegółowości były wspomagane przez publicystykę poprawnościową. Błędy spotykane $\mathrm{w}$ prasie oceniano jednoznacznie negatywnie, wymagając od dziennikarzy stałej pracy nad doskonaleniem kultury wypowiedzi (Kita 2013a).

Nadal pojawiają się prace ewidencjonujące językowe potknięcia dziennikarzy (Kita 2013a: 327-336), a hegemonia tej problematyki znajduje odzwierciedlenie w niejęzykoznawczych opracowaniach komunikatów medialnych (Kaliszewski 2006: 175-198).

Rola hegemona utrwalała się nawet wtedy, gdy lingwiści nie postrzegali przedmiotu badań jako poznawczego monolitu. Wychodząc od tezy o wzajemnym oddziaływaniu różnorodnych mediów, starali się odszukać w tak konstruowanym obszarze badawczym zbiór cech wyróżniających język mediów (po zmianach ustrojowych w Polsce), opisać formy językowe ilustrujące zaobserwowane procesy, dla przykładu ekspansję potoczności (czy nawet wulgarności), unifikację języka w mediach, upowszechnianie się kiczu czy dążenie do ekspresywnej wyrazistości komunikatów, a więc poetykę udramatyzowania przekazu, a także prymat estetyki nadmiaru (Majkowska 2000: 232-243; 2007: 93-103).

Perspektywa tak sprofilowanych analiz czyniła z językoznawcy badacza otwierającego się na inspiracje płynące z zewnątrz, uwzględniającego przynajmniej wybrane problemy z zakresu medioznawstwa. Dynamika przeobrażeń mediów spowodowała ponadto zmianę w sposobie postrzegania przedmiotu badań. Język mediów przestał się jawić jako monolit czy też zbiór form uwarunkowanych tendencjami w funkcjonowaniu mediów. Zaczęto go postrzegać jako twór osobliwy, heterogeniczny i zmienny. Upowszechniła się zaproponowana przez Stanisława Gajdę metafora tygla stylowego jako formuła oddająca istotę rozpatrywanego zjawiska (Pisarek 1978: 19-27). Językoznawcy rozpoczęli stopniowe przechodzenie na nowe pozycje $\mathrm{w}$ medialnym polu badawczym, uwzględniając przeobrażenia zarówno w samych mediach, jak i w metodologii lingwistycznej. W żadnym z wymienionych obszarów nie ma już obecnie miejsca dla językoznawcy hegemona.

Od pewnego czasu badacze mediów - lingwiści występują w roli suwerenów. Językoznawca suweren wybiera zakres i sposób dookreślenia przedmiotu badań, sytuuje swe rozważania $\mathrm{w}$ określonym nurcie własnej dyscypliny (powielanym lub modyfikowanym), wybiera postawę otwartości na inspiracje płynące $\mathrm{z}$ teorii komunikacyjnych i innych profili badawczych skupionych w ramach medioznawstwa. Jakie są podstawowe przejawy tej reorientacji?

$\mathrm{Na}$ pierwszym miejscu, nie z racji wagi podejmowanej problematyki, lecz z powodu kontynuacji badań, umieszczam problematykę poprawnościową. Ze względu na przeobrażenia samej koncepcji kultury języka, a zwłaszcza jej otwar- 
cia na pragmalingwistykę (także retorykę), estetykę i etykę słowa (Markowski 2006) oraz radykalną modyfikację sposobów traktowania błędów przez media, $\mathrm{w}$ językoznawczych prezentacjach tych zjawisk nastąpiły znamienne przewartościowania. Inwentaryzowanie, a zwłaszcza piętnowanie błędów odszukanych w komunikatach medialnych ustępuje miejsca ich interpretacji w duchu nowej koncepcji kultury języka (Kukieła 2010: 305-318) lub z odwołaniem się do zjawiska mediatyzacji błędów. Premiując atrakcyjność komunikatów, media dowartościowują zachowania niestandardowe (bez względu na ich zgodność z normą językową i funkcjonalność rozumianą jako komunikacyjna doraźna użyteczność) (Kita 2008: 60-61).

Skrupulatny badacz owych zagadnień Kazimierz Ożóg przedstawia najważniejsze zakresy medialnych oddziaływań na język, wymieniając konsumpcyjną wizję świata, wizję przez media zapośredniczoną i narzucaną oraz wizję, w ramach której kształtuje się wzorce językowe rzadko akceptowalne dla lingwisty (2009: 11-20).

Nie tylko kwestie poprawnościowe doczekały się nowych interpretacji w opracowaniach językoznawczych. Suwerenność lingwistów przyjmuje ostatnio kolejne zmodyfikowane formy. Językoznawcy zmieniają zakresy analiz lub jedynie prezentowane $\mathrm{w}$ opracowaniach punkty widzenia. Język mediów jest charakteryzowany $w$ nawiązaniu do dawnych badań $\mathrm{z}$ uwzględnieniem perspektywy medioznawczej. Punktem wyjścia czyni się przeobrażenia, jakim media podlegają od czasu transformacji ustrojowej, wyodrębniając takie cechy, jak: synkretyzm estetyczny i stylistyczny, transgeniczność, interaktywność i interakcyjność, kreatywność, dominację ikoniczności (Kudra 2008: 55). W tak zarysowanej perspektywie analizowane są zarówno zjawiska już wcześniej dostrzeżone, jak i nowe, a więc ekspansja potoczności, neutralizacja oficjalności, kreatywność leksykalna, grafizacja wybranych części komunikatów prasowych, a także unifikacja językowa (Kudra 2008: 56-60).

Warto przy okazji odnotować ostrożność w postawie badaczy, którzy uwypuklają niepełność i szkicowy w istocie charakter swych uwag. Lingwista suweren dostrzega ograniczenia stosowanej aparatury analitycznej, powagę problemów i stopień ich skomplikowania. Lingwista suweren często przerywa ciągłość strumienia publikacji naukowych (a więc także badań), porzucając wcześniejsze wątki lub nadając im nowe oblicze badawcze bez eksplicytnych nawiązań do tradycji. Lingwista suweren wybiera świadomie ograniczony zakres pola badawczego oraz sposób jego charakterystyki.

Ilustracją tej postawy jest włączenie się językoznawców w problematykę opisu medialnej wizji świata oraz mediatyzacji, czyli ,,pośrednictwa mediów w poznawaniu świata, wpływaniu przez media na postrzeganie przez człowieka rzeczywistości niedostępnej bezpośredniemu doświadczeniu" (Kołodziej 2006: 118). Medioznawcy mówią w tym kontekście o deformacji obrazu, wiążąc owe kwestie $\mathrm{z}$ rolą przypisywaną mediom, ze sposobem wpływu mediów zwłaszcza na świat 
polityki (Kołodziej 2006: 118-119)². Lingwiści przychodzą na wskazane pole badawcze z własną tradycją i własną aparaturą pojęciową. Odnoszą wspomnianą problematykę do pojęcia językowego obrazu świata. Przy założeniu, że ludzkie poznanie rzeczywistości zależy od jego interpretacji zawartej w języku, badacze formułują wniosek o niemożności ,ucieczki” od wspomnianego zapośredniczenia (językowego i kulturowego) i medialny obraz świata uznają za reinterpretację jego wizji językowej (Kępa-Figura, Nowak 2006: 51-62). Rozwijając wspomniane zagadnienia, zainteresowani problematyką językoznawcy interpretują podstawowe dla mediów działanie komunikacyjne, jakim jest informowanie, w kategoriach komunikowania, czyli prezentacji faktów z określonego punktu widzenia (Nowak, Tokarski 2007: 11).

W opracowaniach językoznawczych problematyka wizji świata jest obecnie reinterpretowana pod względem teoretycznym, a także doprecyzowywana w analizach zagadnień szczegółowych (Tokarski 2013: 313-323).

$\mathrm{Na}$ gruncie medioznawstwa prowadzi się natomiast (nie bez udziału lingwistów) szeroko zakrojoną dyskusję nad pojęciem medialnego obrazu świata. Oto jedna $\mathrm{z}$ proponowanych eksplikacji

Medialny obraz świata jest [...], mówiąc metaforycznie, utkany z różnych form znakowych: obrazów, słów, dźwięków, form symbolicznych, pojęć, dyskursów, narracji, gatunków, które układają się w globalnie spójną wizję określonej rzeczywistości. Jest to obraz (reprezentacja mentalna), który pojawia się w umyśle odbiorcy wskutek odczytania treści przekazu (Ptaszek 2015: 15-16).

Aby zamknąć wątek suwerennych językoznawczych badań medialnej wizji świata, trzeba jeszcze wspomnieć o prężnym nurcie charakteryzowania komunikacji publicznej, odzwierciedlanej w określony sposób w mediach, o kwestii perswazji i manipulacji (Krzyżanowski, Nowak 2004) oraz humoru (Kamińska-Szmaj 2001; Piechota, Stachyra, Nowak 2012; Wojtak 2015: 151-170) lub agresji, a przy okazji miejsca mediów w modelu komunikowania publicznego (Kamińska-Szmaj 2007).

Językoznawca suweren, pomny niebezpieczeństw związanych z rozmyciem się zagadnień ujmowanych $\mathrm{z}$ różnych punktów widzenia, może rozmyślnie zwężać zakresy rozważań, wzbogacając interpretację uwzględnianych zjawisk dzięki otwarciu na inspiracje płynące z innych dyscyplin. Dobrą ilustracją takich postaw są studia i większe opracowania poświęcone nazwom własnym funkcjonującym w obszarze mediów. Wieloaspektowym badaniom podlega w nich kwestia udziału

${ }^{2}$ Warto w tym miejscu odesłać do refleksji Macieja Mrozowskiego, który w książce Media masowe. Władza, rozrywka, biznes stwierdza: „obraz świata w mediach jest różnorodny, fragmentaryczny, przypadkowy i zmienny. Podobnie jak kalejdoskop jest on nieskończonym ciągiem coraz to nowych konfiguracji i podobnie jak w kalejdoskopie każdą taką konfigurację tworzą jeśli nie te same to przynajmniej dość podobne elementy" (2000: 303).

${ }^{3}$ Warto w tym miejscu odnotować ogromne zróżnicowanie postaw i optyk badawczych, wprowadzanej aparatury pojęciowej, zakreślania zakresów analiz itd. (Tokarski 2015: 47-60). 
onimów w kształtowaniu medialnej wizji świata (Skowronek, Rutkowski 2004; Rutkowski 2007). Opracowania $\mathrm{z}$ tego kręgu stanowią cenny wkład zarówno do medioznawstwa, jak i lingwistyki, zwłaszcza subdyscypliny, jaką jest onomastyka.

Językoznawca suweren może zmienić medioznawczą orientację badawczą, zwłaszcza wtedy, gdy jest do pewnego czasu w niej pomijany, niezauważany lub niezrozumiany. Przykładem funkcjonowania takiego zjawiska jest obszar badań genologicznych. Medioznawcy wyrażają przekonanie o konieczności wyodrębniania w ramach genologii, czyli nauki o gatunkach wypowiedzi (pierwotnie rozwijanej na gruncie literaturoznawstwa), odłamu medioznawczego. W Słowniku terminologii medialnej odnajdujemy hasło genologia dziennikarska z następującym objaśnieniem:

Dział wiedzy o dziennikarstwie zajmujący się opracowywaniem historii gatunków dziennikarskich [...]; badaniem kulturowych źródeł i kontekstów gatunków dziennikarskich; prowadzeniem badań nad wzajemnym przenikaniem się różnych form i gatunków dziennikarskich; badaniem języka i stylu gatunków dziennikarskich; analizowaniem rzetelnego opisywania przez dziennikarzy współczesnej rzeczywistości w poszczególnych gatunkach [...]. Genologia dziennikarska jest młodą dyscypliną nauki, wywodzącą się z teorii literatury i genologii literackiej (Pisarek red. 2006: 68).

Brak w tej prezentacji odniesień do prężnego nurtu genologii dziennikarskiej (pozostańmy przy tej nazwie) wywodzącego się z lingwistyki. W ramach tego nurtu, co warto uwypuklić, przedstawia się gatunki dziennikarskie związane z różnego typu mediami. Sama genologia lingwistyczna zaś jest otwarta na całą gamę dyscyplin, które dostarczają aparatury pojęciowej, pozwalają odpowiednio głęboko profilować samo pojęcie gatunku oraz twórczo interpretować wyznaczniki pojedynczych gatunków lub ich grup. Relacje tej dyscypliny z innymi badawczymi optykami funkcjonującymi na gruncie literaturoznawstwa oraz medioznawstwa nie są jednak odniesieniami jednowymiarowymi. Relacje dwustronne są tworzone z trudno czasem uchwytnym udziałem innych powiązań. Przeważają, jak do tej pory, postawy hegemonistyczne, polegające na próbach podporządkowania w ramach badań nad konkretnymi obiektami komunikacyjnymi innych optyk badawczych optyce reprezentowanej przez określonego badacza. Ogłasza się więc prymat genologii literaturoznawczej, czyniąc ją punktem wyjścia badań nad gatunkami dziennikarskimi oraz narzędziem interpretacji wielu zjawisk z zakresu ich funkcjonowania (Furman, Kaliszewski, Wolny-Zmorzyński 2006: 13-35). Szuka się nowych dróg badawczych, proklamując oddzielną subdyscyplinę nazwaną genologia multimedialną.

Lingwistycznym badaniom nad gatunkami funkcjonującymi w mediach towarzyszy pogłębiająca się refleksja nad założeniami genologii lingwistycznej ${ }^{4}$, a tak-

${ }^{4}$ Z opracowań syntetyzujących należy wymienić: Witosz 2005; Ostaszewska 2008; Loewe 2008; Wojtak 2014b: 7-22. 
że tekstologii (Bartmiński, Niebrzegowska-Bartmińska 2009, Wojtak 2013: 85107) oraz analizy dyskursu (Witosz 2009; Żydek-Bednarczuk 2013b: 179-197; 2013a: 347-379; Kita 2013a: 199-288; 2013b: 313-346; Loewe 2013: 289-311; Wojtak 2010; 2015: 31-44, 95-105).

Na gruncie lingwistyki sytuują się stosunkowo liczne już charakterystyki gatunków z różnych mediów. Są one jednak w zróżnicowany sposób sprofilowane, stanowiąc próby przeniesienia na obszar zjawisk medialnych wybranych w istocie kwestii, dobrze oświetlonych w lingwistyce otwartej na inspiracje psychologii czy socjologii ${ }^{5}$.

Aparatura pojęciowa oraz metody analizy i interpretacji genologicznej wywodzące się z lingwistyki pozwoliły mi na suwerenną charakterystykę wyspecjalizowanego ugrupowania gatunków dziennikarskich, jakim są gatunki prasowe. W monografii oraz podręczniku akademickim zanalizowałam najważniejsze gatunki prasowe, odwołując się do własnych propozycji pojmowania wzorca gatunkowego (jako schematu organizacji tekstu), jego aspektów (całościowo ujmowany wzorzec zawiera aspekt strukturalny, pragmatyczny, poznawczy i stylistyczny), a także wariantów (kompletny zbiór obejmuje: wariant kanoniczny, warianty alternacyjne i adaptacyjne) (Wojtak 2004; 2008). Całościowy ogląd zagadnienia oznacza w przywoływanych opracowaniach: 1) metodologiczne zakorzenienie $w$ badaniach lingwistycznych $z$ uwzględnieniem osiągnięć prasoznawstwa, 2) możliwość uzupełnienia i zmodyfikowania typologii gatunków (łączę ujęcie hierarchiczne z polarnym), 3) wieloaspektowość analiz poszczególnych gatunków, obejmującą: dookreślenie zbioru wariantów wzorca konkretnych gatunków prasowych, zwrócenie uwagi zarówno na morfologię tekstu prasowego, jak i jego komunikacyjne zakorzenienie, preferowaną wizję świata oraz zakresy zróżnicowania stylistycznego, co pozwoliło uchwycić dynamikę relacji między schematycznością a elastycznością wzorców i zakresami dziennikarskiej kreatywności, 4) monograficzne charakterystyki poszczególnych gatunków z uwzględnieniem ich historii, sposobów prezentowania w dotychczasowych badaniach i roli we współczesnej prasie.

Monografia poświęcona gatunkom prasowym wnosi nowe treści nie tylko do poznania bezpośredniego przedmiotu badań, lecz także do teorii genologicznej, w której ugruntowały się proponowane przeze mnie sposoby rozumienia takich pojęć, jak: gatunek, wzorzec gatunkowy, warianty i aspekty wzorca, sfera paradoksów gatunku, wielostylowość. W obu opracowaniach znalazły się kompleksowe charakterystyki zarówno gatunków opisywanych wcześniej stosunkowo dokładnie, lecz w ramach odmiennych opcji metodologicznych (na przykład reportażu, wywiadu, felietonu), jak i traktowanych po macoszemu (na przykład

${ }^{5}$ Por. dla przykładu monografię i artykuły poświęcone wybranym typom komunikatów telewizyjnych: Ptaszek 2007; Skarżyńska 2008a; 2008b oraz inwentaryzację badań w: Kita 2013a: 218-220. 
komentarza, sylwetki czy editorialu). Podręcznik łączy zwięzłe charakterystyki poszczególnych gatunków z przykładowymi analizami ich tekstowych realizacji oraz serią ćwiczeń, pokazujących te gatunki nie tylko od strony warsztatowej, lecz także jako gotowe komunikaty (nie zawsze wzorcowe) ${ }^{6}$.

Suwerenność badawcza językoznawcy włączającego się w refleksję medioznawczą oznaczać może odrębne propozycje rozwiązywania analogicznych problemów. Do zbioru zagadnień, które wciąż budzą kontrowersje, stanowią wręcz wyzwanie badawcze, zaliczyć można śmiało kwestię funkcjonowania odmiany językowej powiązanej z mediami. Zaczynałam ten artykuł od wspomnianej problematyki, stawianej w rzędzie zadań badawczych bez większych obaw w epoce hegemonii językoznawstwa na różnych polach poznawczych. Obecnie problem jawi się jako szczególnie skomplikowany. Jest w literaturze przedmiotu formułowany w nowy sposób. Już zasadniczo nikt się nie spiera o nazwę (język mediów, język $w$ mediach, styl dziennikarski, publicystyczny), niewiele można znaleźć nowych uwag na temat statusu odmiany czy też zasadności jej wyodrębniania (Wojtak 2015: 45-62). Sposób funkcjonowania języka w przekazach medialnych jest łączony z badaniami dyskursywnymi. Kłopot jednak w tym, że samo pojęcie dyskursu nie uzyskało do tej pory jednoznacznej eksplikacji. Problematyka ta jeszcze powróci. W tym miejscu chcę pokazać nieco inne zagadnienie. Chodzi o autonomiczne rozwiązywanie tych samych problemów badawczych przez różnych autorów.

Kwestia funkcjonowania różnych sposobów wysłowienia w mediach jest przez lingwistów nadal traktowana jako zadanie badawcze. Aby pokazać zakresy zróżnicowań postaw i metodologicznych optyk, zaprezentuję dwie monografie poświęcone językowi współczesnej polskiej prasy. Autorki opracowań nie zasklepiają swych rozważań w wąsko rozumianej lingwistycznej niszy, lecz starają się pokazać zjawiska językowe, charakterystyczne dla prasy, na szerokim tle.

Maria Teresa Lizisowa szeroko zakreśla zakresy prezentowanej problematyki (2009). Na początku autorka wprowadza zwięźle w tajniki dziennikarstwa, a zwłaszcza charakteryzuje wieloaspektowo komunikację, jaką organizują media. Odwołując się do opracowań socjologicznych i medioznawczych, kreśli obraz dziennikarstwa, jego rangi społecznej, stylu funkcjonowania, roli dziennikarzy jako organizatorów i współtwórców komunikacji o wymiarze ogólnospołecznym. Ważnym fragmentem tej części książki jest rozdział poświęcony językowi jako narzędziu pracy dziennikarza. W dalszej części podręcznika badaczka snuje refleksje na temat języka, a także odmian współczesnej polszczyzny. Autorka łączy w swych wywodach rozważania dotyczące podstawowych parametrów zróżnicowań współczesnej polszczyzny, uzupełniając tak skonfigurowaną charakterystykę odmian z problematyką funkcji komunikacyjnych języka oraz zagadnieniami

${ }^{6}$ Warto dodać, że lingwistyczne badania nad gatunkami prasowymi zostały dostrzeżone przez prasoznawców (Mich 2007: 256). 
genologii. Są w tej części książki pewne ograniczenia związane ze stanem badań nad niektórymi odmianami polszczyzny, ale samo uświadomienie czytelnikom istnienia omówionych zróżnicowań oraz wskazanie, w jaki sposób i w jakim zakresie będą musieli się z nimi liczyć we własnej pracy redakcyjnej, trzeba uznać za walor opracowania.

W kolejnych partiach książki czytelnik znajdzie oryginalną prezentację obecności poszczególnych stylów funkcjonalnych współczesnej polszczyzny w wypowiedziach prasowych. Autorka nie gubi z pola widzenia żadnego ze stylów funkcjonalnych, gdyż każdy z nich może się pojawić w prasie.

Badaczka umiejętnie łączy w podręczniku rozległe pokłady erudycji z praktyką analityczną, dołączając do grona lingwistów, którzy pokazują, że metodologia językoznawcza jest w badaniu języka prasy - jego funkcjonalnego zróżnicowania w szczególności - niezwykle inspirująca i owocna. W ujednoliconej metodologicznie charakterystyce spotykają się $\mathrm{w}$ tej książce zagadnienia istoty dziennikarskiej kreatywności, dziennikarskiego operowania słowem potocznym, naukowym, religijnym, urzędowym i prawniczym. Panorama to zaiste imponująca.

Odmienną propozycję ujmowania języka współczesnej prasy zawiera moja książka (Wojtak 2010). Kategorią porządkującą charakterystykę czynię głosy, ujmowane jako zbiór zasad i sposobów komunikowania się za pośrednictwem prasy. Głosy są interpretowane jako wypowiedzi (ich zbiory lub fragmenty) ukształtowane pod względem pragmatycznym (co do celów) oraz językowym, a publikowane w prasie tradycyjnej. Komunikację prasową traktuję jako wielość głosów, a więc odnoszę do kategorii dyskursu, definiowanego wstępnie jako „,ałokształt praktyk komunikacyjnych związanych z określoną dziedziną ludzkiej aktywności" (Wojtak 2010: 17). Jest on ujmowany polifonicznie i charakteryzowany przez pryzmat kilku pasm komunikacyjnych, czyli typów zachowań językowych podporządkowanych określonym celom, wyprofilowanych gatunkowo, a zatem zarówno tematycznie, jak i stylistycznie.

Dyskurs prasowy ujmowany globalnie jest utkany z innych dyskursów i ma charakter absorpcyjny. Może bowiem wchłaniać wszelkie inne dyskursy. Wyróżniam przy tym absorpcję przytoczeniową $\mathrm{i}$ interpretacyjną. $\mathrm{Z}$ pierwszym wypadkiem mamy do czynienia wtedy, gdy prasa prezentuje dyskurs $\mathrm{X}$, reprodukując jego składniki i zachowując ich autonomię. W drugim wypadku dyskurs jest wchłaniany w taki sposób, że nie zachowuje autonomii, lecz podlega różnorodnym (zwykle sprofilowanym gatunkowo) przekształceniom. Istotę referowanego zagadnienia ujmuję w następujących słowach:

Jeśli popatrzymy na te zjawiska od strony rezultatów, to dyskurs prasowy będzie się nam jawił jako dyskurs utkany cytatowo lub transformacyjnie $\mathrm{z}$ innych dyskursów. W jego ramach da się wyodrębnić zbiór dyskursów X i dyskursów o X. Będzie to dla przykładu dyskurs polityki i dyskurs o polityce, dyskurs religii i dyskurs o religii, dyskurs prawa i dyskurs o prawie, [...] dyskurs nauki (w wersji popularyzatorskiej) i dyskurs o nauce [...]. Dyskurs medialny utkany $\mathrm{z}$ innych dyskursów zmienia się $\mathrm{w}$ rytmie własnym, ale z uwzględnieniem rytmu przeobrażeń 
dyskursów absorbowanych [...]. Charakteryzuje go zatem transgresyjność związana z otwieraniem zarówno granic samego dyskursu (co wiąże się z absorpcją oraz ekspansją na inne obszary dyskursywne), jak i granic różnych aspektów (płaszczyzn) dyskursu (Wojtak 2010: 21-22).

Po scharakteryzowaniu kilku typowych dla współczesnej prasy głosów: 1) wyprofilowanych ze względu na genezę (głosy i odgłosy codzienności; głosy egzotyczne, związane z użyciem gwary ludowej, socjolektów lub składników innych języków), 2) zdeterminowanych funkcjonalnie (głosy prześmiewców, językowych wynalazców, indywidualistów oraz głosy wypełniające luki komunikacyjne) mogłam formułować ogólne tezy na temat dyskursu prasowego. Znalazły się wśród nich następujące konstatacje: dyskurs prasowy jest politematyczny, poliintencyjny, odznacza się polipodmiotowością, jest poligatunkowy i polifoniczny (Wojtak 2010: 183-185).

Wprowadzając podmiotową perspektywę, mogłam w prezentowanej książce nawiązać do tradycji badań nad językiem prasy, prezentować jego składniki w określonych konfiguracjach komunikacyjnych, weryfikować liczne sądy generalizujące i upraszczające wybrane zagadnienia, pokazywać w nowym świetle istotę i dynamikę przemian komunikacji medialnej, a także pozostając na gruncie lingwistyki, uwzględniać inspiracje płynące z innych dyscyplin (Wojtak 2015: $31-44,95-105)^{7}$.

Językoznawcza suwerenność w badaniach mediów oznacza obecnie (paradoksalnie) konieczność uwzględnienia dynamiki przeobrażeń przedmiotu badań, reorientacji metodologicznej we współczesnej lingwistyce, jej otwarcia nie tylko na inspiracje płynące $\mathrm{z}$ rodzimych nurtów czy szkół badawczych, lecz także uwzględniania kontekstów tworzonych przez badania zagraniczne.

Jednym $\mathrm{z}$ istotnych zjawisk, przeobrażających lingwistyczne badania nad mediami, staje się proklamowanie odrębnej subdyscypliny, określonej mianem mediolingwistyki. Jej podstawowe założenia sformułował (suwerennie) Bogusław Skowronek (2013). Ważnym zapleczem teoretycznym dla mediolingwistyki czyni badacz lingwistykę kulturową i semantykę kognitywną, ponieważ, jak pisze, ,pomiędzy mechanizmami, które decydują o indywidualnych procesach poznawczych [...], a mechanizmami społecznego oddziaływania mediów [...] można znaleźć zasadnicze podobieństwo" (Skowronek 2013: 135). Mediolingwistyka jest $\mathrm{w}$ przedstawianym ujęciu osadzona ponadto na gruncie pragmatyki oraz socjolingwistyki (Skowronek 2013: 137). Twórca koncepcji badań mediolingwistycznych uważa, iż proklamowana przezeń dyscyplina może się w sposób naturalny posługiwać aparaturą pojęciową wypracowaną przez dyscypliny traktowane jako jej zaplecze. „Jednak metodologią nadrzędną - stwierdza kategorycznie - spajającą wszelkie procedury analityczne w omawianym projekcie jest

${ }^{7}$ Przyjęte przeze mnie założenia zostały zaakceptowane przez innych lingwistów (Żydek-Bednarczuk 2013b: 190; Kita 2013a: 230). 
krytyczna analiza dyskursu KAD" (Skowronek 2013: 154). Autorska propozycja wspomnianego lingwisty może być uznana za przejaw suwerennego dookreślenia przestrzeni badawczej, wyboru perspektywy opisu, wskazywania preferowanych przez badacza punktów widzenia, dobierania metod badawczych hierarchizowania problematyki oraz ustalania preferencji poznawczych (zob. rozdział IV omawianej książki, poświęcony językowym odmianom medialnym).

Stan zawieszenia między przeszłością lingwistycznej eksploracji medialnego pola poznawczego a dynamiczną i labilną teraźniejszością znakomicie ilustrują ujęcia syntetyzujące (Kita, Loewe red. 2014; Malinowska, Nocoń, Żydek-Bednarczuk red. 2013). Wyraźnie widać, że problematyka komunikacji medialnej się rozwarstwia, łącząc koncepcje zakorzenione w tradycji (co sugeruje sam termin język w mediach) z nową i, jak sądzą badacze, bardzo cenną poznawczo perspektywą dyskursywną. Powstaje zarówno siatka pojęć, jak i subsystem terminologiczny (dyskurs medialny, prasowy, radiowy, telewizyjny, internetowy), który jest propozycją odbiegającą od ujęcia sytuowanego w ramach, wspominanej już, krytycznej analizy dyskursu KAD.

Obiecujące perspektywy rysują się także w związku z owocami pracy thumaczy (germanistów), którzy przybliżają najistotniejsze osiągnięcia niemieckich lingwistów uprawiających, by tak rzec, medialne pole badawcze. Niemieckojęzyczna lingwistyka mediów opiera ,swoje punkty ciężkości na trzech filarach: rodzajach tekstów medialnych (genologia tekstów medialnych), teoriach multimodalności oraz badaniach kontrastywnych" (Opiłowski, Jarosz, Staniewski 2015: 9). Za priorytety badawcze w niemieckiej lingwistyce mediów uznaje się interakcję kodów semiotycznych w tekście, modele analizy oraz perspektywę międzykulturową (Opiłowski, Jarosz, Staniewski 2015: 12). W polskiej mediolingwistyce zagadnienia te nie są wystarczająco mocno prezentowane (Opiłowski, Jarosz, Staniewski 2015: 12-13). Antologia przekładów rozpraw lingwistów niemieckich dookreślających podstawowe założenia lingwistyki mediów, zajmujących się cechami i metodami analizy tekstów medialnych, transmedialnymi badaniami nad dyskursem oraz analizujących tekst medialny w perspektywie porównawczej, diachronicznej i internetowej może wiele zmienić w ujmowaniu zagadnień medioznawczych przez lingwistykę w Polsce.

W konkluzji trzeba uwypuklić, iż czas obecny jest dla lingwistycznych badań nad mediami w Polsce okresem rozeznania i suwerennych poszukiwań, rozwijania indywidualnych pasji badawczych, stawiania na podmiotowość ujęć, a zarazem rozproszenia, by nie rzec rozproszkowania, badań, dowartościowywania nie tylko indywidualnych dróg poznawczych przemierzanych przez konkretnych językoznawców, lecz cząstkowych ujęć określonych zjawisk, ponieważ materia badawcza jest tak bogata, polimorficzna i zmienna, że wymyka się przyjmowanych lingwistycznym metodom, poznawczym kategoriom, prowokując do poszukiwania nowego instrumentarium badawczego. Bogactwo propozycji nie oznacza 
poznawczego chaosu, lecz koegzystencję kilku rozwiązań o charakterze podmiotowym, których przydatność w badaniach i trwałość będzie można ocenić w przyszłości. Jedno jest pewne - nie będzie już płynnego przejścia między tradycją (hegemonistyczną) a innowacyjnością (suwerenną), gdyż na taki styl postępowania badawczego nie pozwala stan współczesnej humanistyki i nauk społecznych, zanurzonych w kulturze indywidualizmu.

\section{Bibliografia}

Bartmiński J., Niebrzegowska-Bartmińska S., 2009, Tekstologia, Warszawa.

Furman W., Kaliszewski A., Wolny-Zmorzyński K., 2006, Gatunki dziennikarskie. Teoria, praktyka, język, Warszawa.

Gajda S., 2000, Media - stylowy tygiel współczesnej polszczyzny, w: Język w mediach masowych, red. J. Bralczyk, K. Mosiołek-Kłosińska, Warszawa, s. 19-27.

Kaliszewski A., 2006, Gatunki dziennikarskie a język, w: K. Wolny-Zmorzyński, A. Kaliszewski, W. Furman, Gatunki dziennikarskie. Teoria, praktyka, język, Warszawa, s. $175-198$.

Kamińska-Szmaj I., 2001, Stowa na wolności, Wrocław.

Kamińska-Szmaj I., 2007, Agresja językowa w życiu publicznym. Leksykon inwektyw politycznych 1918-2000, Wrocław.

Kępa-Figura D., Nowak P., 2006, Językowy obraz świata a medialny obraz świata, ,Zeszyty Prasoznawcze", z. 1-2, s. 51-62.

Kita M., 2008, Medialna kariera błędu językowego, w: Błąd językowy w perspektywie komunikacyjnej, red. M. Kita, M. Czempka-Wewióra, M. Ślawska, Katowice, s. 60-72.

Kita M., 2012, Konsiliencja, interdyscyplinarność, transdyscyplinarność, w: Transdyscyplinarność badań nad komunikacja medialna. Stan wiedzy i postulaty badawcze, red. M. Kita, M. Ślawska, Katowice, s. 11-30.

Kita M., 2013a, Dyskurs prasowy, w: Przewodnik po stylistyce polskiej. Odmiany wspótczesnej polszczyzny, red. E. Malinowska, J. Nocoń, U. Żydek-Bednarczuk, Kraków, s. 199-288.

Kita M., 2013b, Dyskurs radiowy, w: Przewodnik po stylistyce polskiej. Odmiany wspótczesnej polszczyzny, red. E. Malinowska, J. Nocoń, U. Żydek-Bednarczuk, Kraków, s. 313-346.

Kita M., Loewe I. (red.), 2014, Język w mediach. Antologia, Katowice.

Kołodziej J., 2006, Mediatyzacja (rzeczywistości społecznej), w: Słownik terminologii medialnej, red. W. Pisarek, Kraków, s. 118.

Krzyżanowski P., Nowak P. (red.), 2004, Manipulacja w języku, Lublin.

Kudra B., 2008, O języku w mediach-uwagi ogólne, w: Wypowiedź dziennikarska. Teoria i praktyka, red. B. Bogołębska, A. Kudra, Łódź, s. 55-61.

Kukieła E., 2010, O kulturze wypowiedzi w mediach, w: O mediach i komunikowaniu. Skrypt dla studentów dziennikarstwa i komunikacji społecznej, red. E. Pleszkun-Olejniczakowa, J. Bachura, M. Worsowicz, Łódź, s. 305-318.

Lizisowa M.T., 2009, Style funkcjonalne w dziennikarstwie prasowym, Kielce. 
Loewe I., 2008, Polska genologia lingwistyczna. Rekonesans, „Tekst i Dyskurs - Text und Diskurs", z. 1, s. 25-35.

Loewe I., 2013, Dyskurs telewizyjny, w: Przewodnik po stylistyce polskiej. Odmiany współczesnej polszczyzny, red. E. Malinowska, J. Nocoń, U. Żydek-Bednarczuk, Kraków, s. 289-311.

Majkowska G., 2000, O języku mediów, w: Dziennikarstwo i świat mediów, red. Z. Bauer, E. Chudziński, Kraków 2000, s. 232-243.

Majkowska G., 2007, Język mediów w perspektywie aksjologicznej, w: Język polski jako narzędzie komunikacji we współczesnym świecie, red. J. Mazur, M. Rzeszutko-Iwan, Lublin, s. 93-103.

Malinowska E., Nocoń J., Żydek-Bednarczuk U. (red.), 2013, Przewodnik po stylistyce polskiej. Odmiany współczesnej polszczyzny, Kraków.

Markowski A., 2006, Kultura języka polskiego. Teoria. Zagadnienia leksykalne, Warszawa.

Mich W., 2007, Badania komunikologiczne w Uniwersytecie Marii Curie-Skłodowskiej, w: Studia nad mediami i komunikowaniem masowym. Prawo. Język. Tekst, red. J. Fras, Toruń, s. 248-273.

Mrozowski M., 2000, Media masowe. Władza, rozrywka, biznes, Warszawa.

Nowak P., Tokarski R., 2007, Medialna wizja świata a kreatywność językowa, w: Kreowanie światów w języku mediów, red. P. Nowak, R. Tokarski, Lublin, s. 9-36.

Opiłowski R., Jarosz J., Staniewski P., 2015, Wstęp - cel antologii, zarys badań, tematyka artykułów, w: Lingwistyka mediów. Antologia tłumaczeń, red. R. Opiłowski, J. Jarosz, P. Staniewski, Wrocław-Dresden, s. 7-19.

Ostaszewska D., 2008, Genologia lingwistyczna jako subdyscyplina współczesnego językoznawstwa, w: Polska genologia lingwistyczna, red. D. Ostaszewska, R. Cudak, Warszawa, s. 11-39.

Ożóg K., 2009, Boskie usta, kultowe dialogi - wpływ mediów na nowe wzorce językowe, w: Ksztaltowanie się wzorów i wzorców językowych, red. A. Piotrowicz, K. Skibski, M. Szczyszek, Poznań, s. 11-20.

Piechota M., Stachyra G., Nowak P., 2012, Rozrywka w mediach. Wybrane zagadnienia, Lublin.

Pisarek W., 1978, Słownik języka niby-polskiego, czyli błędy językowe w prasie, WrocławWarszawa-Kraków-Gdańsk.

Pisarek W. (red.), 2006, Słownik terminologii medialnej, Warszawa.

Pisarek W., 2007, Pierwsze polskie książki o języku prasy, w: W. Pisarek, O mediach i ję$z y k u$, Kraków, s. 201-214.

Ptaszek G., 2007, Talk show. Szczerość na ekranie?, Warszawa.

Ptaszek G., 2015, Jak badać medialny obraz świata?, w: Wspótczesne media. Medialny obraz świata, t. 1: Zagadnienia teoretyczne, red. I. Hofman, D. Kępa-Figura, Lublin, s. 13-23.

Rutkowski M., 2007, Nazwy własne i ich denotacje w rzeczywistości medialnej, w: Kreowanie światów w języku mediów, red. P. Nowak, R. Tokarski, Lublin, s. 155-170.

Skarżyńska M., 2008a, Język prawników w służbie reportażu telewizyjnego, w: Najnowsze słownictwo a współczesne media elektroniczne, red. R. Pawelec, M. Krysińska, Warszawa, s. 121-141. 
Skarżyńska M., 2008b, Słowo pisane a/i słowo mówione. Ikoniczność przekazu telewizyjnego, w: Najnowsze słownictwo a wspótczesne media elektroniczne, red. R. Pawelec, M. Krysińska, Warszawa, s. 143-156.

Skowronek B., 2013, Mediolingwistyka. Wprowadzenie, Kraków.

Skowronek K., Rutkowski M., 2004, Media i nazwy. Z zagadnień onomastyki medialnej, Kraków.

Tokarski R., 2013, Światy za słowami. Wykłady z semantyki leksykalnej, Lublin.

Tokarski R., 2015, Skrypty w językowym i tekstowym obrazie świata, w: Współczesne media. Medialny obraz świata, t. 1: Zagadnienia teoretyczne, red. I. Hofman, D. Kępa-Figura, Lublin, s. 47-60.

Witosz B., 2005, Genologia lingwistyczna. Zarys problematyki, Katowice.

Witosz B., 2009, Dyskurs i stylistyka, Katowice.

Wojtak M., 2004, Gatunki prasowe, Lublin.

Wojtak M., 2008, Analiza gatunków prasowych. Podręcznik dla studentów dziennikarstwa i kierunków pokrewnych, Lublin.

Wojtak M., 2010, Głosy z teraźniejszości. O języku współczesnej polskiej prasy, Lublin.

Wojtak M., 2013, Tekst i jego gatunki w ostatnim siedemdziesięcioleciu, w: 70 lat wspótczesnej polszczyzny. Zjawiska. Procesy. Tendencje. Ksiega jubileuszowa dedykowana profesorowi Janowi Mazurowi, red. A. Dunin-Dudkowska, A. Małyska, Lublin, s. $85-107$.

Wojtak M., 2014a, Jezykoznawca na medialnym polu badawczym, „Stylistyka” 23, s. $163-178$.

Wojtak M., 2014b, Sporne i bezsporne problemy współczesnej genologii, „Poradnik Językowy", z. 8, s. 7-22.

Wojtak M., 2015, Rozłożone gazety. Studia z zakresu prasowego dyskursu, język i stylu, Lublin.

Zbróg P., 2007, Najczęstsze przykłady naruszania normy językowej w prasie, w: Język polski XXI wieku: analizy, oceny, perspektywy, red. G. Szpila, Kraków, s. 327-336.

Żydek-Bednarczuk U., 2013a, Dyskurs internetowy, w: Przewodnik po stylistyce polskiej. Odmiany współczesnej polszczyzny, red. E. Malinowska, J. Nocoń, U. Żydek-Bednarczuk, Kraków, s. 347-379.

Żydek-Bednarczuk U., 2013b, Dyskurs medialny, w: Przewodnik po stylistyce polskiej. Odmiany współczesnej polszczyzny, red. E. Malinowska, J. Nocoń, U. Żydek-Bednarczuk, Kraków, s. 179-197. 